International Journal of Multidisciplinary Research AND ANALysis

ISSN[Online] : 2643-9875 || ISSN[Print] : 2643-9840

Volume 3 Issue 08 August 2020

DOI: 10.47191/ijmra/v3-i8-02, Impact Factor: 5.522

Page No : $80-84$

\title{
Modern Methods and Means of Providing the Press and Information Organizations with Information Resources
}

\author{
Gulrukhsor Sayriddinovna Kurbonova \\ Corrector of the Press Editorial Publishing Department, Tashkent Pediatric Medical Institute
}

\begin{abstract}
This article discusses the methods and means of satisfying the student's need for information resources of the press and information organizations, as well as the resources used in the formation of existing concepts in the field, using modern concepts, to further improve their relevance to the topic. The article used various methods and tools to further develop the provision of information resources to the press and information organizations in order to deliver and ideally use them for the general public.. Each concept is clearly stated and will certainly be effective in providing information resources to the press and information organizations. At a time when the provision of information resources for the press and media in our country has become a global problem, the suggestions and recommendations contained in the article are relevant, this article was written with the intention to use them and apply them to every press and information organization.
\end{abstract}

Keywords: information, press, organization, media, journalism, information technology, information, news, media, method, modern, future, global, newspaper, magazine, television, radio, internet, website.

\section{INTRODUCTION}

In the concept of further deepening democratic reforms and the development of civil society in our country, special attention is paid to reforming the information sphere, ensuring transparency of public administration, freedom of information and speech. This, in turn, plays an important role in protecting the constitutional right to information, increasing the responsibility and accountability of state bodies and administration.

Our Constitution enshrines the right of everyone to freedom of thought, speech and religion, the right to seek, receive and disseminate information of his choice. On this basis, a number of laws have been adopted in this area. In particular, the Law "On Mass Media”, "On Principles and Guarantees of Freedom of Information”, "On Guarantees and Freedom of Information”, "On Copyright and Related Rights" and a number of other laws on the free and accelerated development of mass media further strengthened the legal guarantees of the industry. This creates a great opportunity for the number and activity of mass media networks to grow steadily. For example, in recent years, additional tax benefits and preferences have been provided for the media, publishing houses, printing companies and media outlets. In the period from 2000 to 2020, the number of print media in our country increased 1.5 times, and the number of electronic media - 14 times.

\section{THE MAIN FINDINGS AND RESULTS}

Today, their total number is 1,672 . Of course, attention and incentives serve to raise the activities of the media to a new level, to inform citizens about the activities of public authorities, to ensure the active participation of the population in the process of state and society building. Transparency of public authorities expands access to information Today, the time itself requires open and transparent activities of public authorities and administration. Such legal norms are reflected in our Constitution and a number of laws. Nevertheless, there was a need to formulate all the norms in this regard as a single law. Based on this, the draft law "On transparency of public administration" was developed. In accordance with the Presidential Decree "On conducting a legal experiment on the draft law of the Republic of Uzbekistan" On transparency of public administration "in March-December last year, the bill was tested on the basis of government agencies in Samarkand and Bukhara regions".

In the process of our national legislation and law-making, this new democratic method has shown its effectiveness in practice. At the initial stage of the legal experiment, the necessary organizational and legal framework was prepared, and the regulations of public authorities were developed in terms of the principle of openness, which is determined by the norms of the 
bill. The public, civil society institutions were informed about the tasks, purpose, procedure and beginning of the experiment. At the main stage, the activities of local self-government bodies, the media, civil society institutions and other information users were organized in accordance with the experimental procedure, and the effectiveness of the draft law was comprehensively assessed.

It was also possible to explain the content of the decisions taken by the heads of government agencies on issues directly affecting the interests of the population through press conferences, briefings, interviews and to develop effective organizational and legal methods in this regard. At the final stage, the subjects of legal experiment summarized and analyzed the results of the experiment, and developed recommendations for further improvement of the bill. In this process, the activities of information services, websites of local public authorities, which are the subjects of legal experiment, have been radically updated, enriched with content. As a result, a unique platform has been created for the population to be closely acquainted with the activities of government agencies. The economic base of the media will be further strengthened.

In the congratulatory message of the head of our state Sh.M.Mirziyoev on the occasion of "June 27 - the Day of Press and Mass Media Workers "Recently, serious work has been done to strengthen the role and prestige of the media in the democratic process, building civil society, the material and technical base and human resources of local newspapers, TV and radio channels, and most importantly, to ensure diversity of opinion in the press. You know very well, of course. "It is clear that providing the press and information organizations with information resources is an important task. Because in the "Provision of press and information organizations with information resources" to provide it with important sources and information resources, foreign experience, methods and tools used in this regard, the provision of information resources to employees of the press and information organizations. At the same time, the press and information organizations play an important role in raising the level of their activities through the use of resources and tools used in the provision of information resources.

In addition, the joint use of information resources by the press and information organizations will become an important basis for increasing their efficiency in a market economy. In this regard, the Law "On guarantees of state support of the media" in our country is aimed at regulating relations related to the provision of legal, economic and organizational support and assistance provided by the state, the use of methods and tools to assist media organizations in providing information resources. Therefore, it provides for the establishment of basic guarantees, principles, forms and infrastructure for state support of the media. Further liberalization of the sector, increasing the share of socially important sources of information and resources in the national information market, training and retraining, providing tax and customs benefits to media outlets fulfilling social orders are of particular importance in the development of the national information space.

Organization and planning of the provision of information resources to the press and information organizations is a system of interaction, which involves the use of a set of available tools to achieve the intended goal of using current tools and methods. Foreign and domestic experience in the field of information shows that information and press organizations, taking into account information resources, achieve more effective results through the use of complex and consistent purpose-linked, methods and tools.

The effectiveness of providing information resources to the press and information organizations is achieved through the wide use of existing methods and tools, one of which complements and strengthens the other. In the press and information organizations, information resources take different forms, and ultimately lead to the formation of specific users for their work efficiency. This saves from unhealthy competition. The methods and means of using information resources by the press and information organizations can be different, in particular:

- publishing information in a special way in the press or on the Internet;

- use of global sources of information or their nationalization and presentation to the public;

- translation from one language to another when using information resources;

- Creating a positive image of the information disseminated to the general public and ensuring their trust in these sources;

- Ensuring the stability of perceptions of the press or information organization through the use of modern methods and tools.

The correct application of the means of use of information resources by the press and information organizations serves the purpose, the characteristics of the object of the organization, its future location. The use of modern methods and means of providing information resources to the press and information organizations differs in characteristics, the main ones of which are listed below.

1. The main object of the information resource is the media, which promotes: news and information; our country, the world. 
2. According to the intended purpose, the press and information organizations are divided into: the method of information, ie the availability of resources to ensure the introduction of new messages and materials to the public; reliable source - serves to increase the number of users or readers; the level of use of modern information technologies by the press and information organization - further increases the demand for print media or mass media.

3. The method of dissemination and promotion of quality efficiency in the regional coverage of information resources of the press and information organizations will be as follows: local; regional; national; international

4. The methods of use of information resources by the press and information organizations on the intensity of influence are as follows: uniform; growing; declining. It is envisaged that the information resources will be leveled in a timely manner, that is, they will be broadcast in the press, radio and television at the same time interval, and that the publications in the media will be the same. For example, a message on the radio - on a set day and time each week. This method demonstrates once again that in cases where the information and press organization is sufficiently popular, it uses unique methods and tools. The growing demand for the press and information organizations is reflected in its widespread use of modern means of communication. For example, modern networks of medium-circulation media will increase the volume and popularity of their publications through the use of online publications and social media, while increasing people's confidence in the accuracy of the resource, which is used in radio, television and Internet publications. both applications are very effective.

The modern way of providing these media and information organizations with information resources is advisable in cases where the prestige and position of the press and information organizations are gradually increasing. A press and information organization that is just starting out should start its way of working in the same way. Always having the necessary information resources is the most appropriate to protect the information provided and to justify public confidence in the future. The more information resources, press and resource base of information organizations expand, the more effective they will be. Dissemination of all sorts of information requires careful preparation of the resource using irregular ones. The use of certain methods and tools in the preparation of materials by the press and information organizations begins with justifying the expediency and necessity. It is recommended to plan the use of information resources in the press and information organizations in the following sequence:

1. Analysis of the situation in the press and information space.

2. Defining information dissemination goals.

3. Defining the target audience for the distribution of the information resource used.

4. Ensuring the reliability of information resources and where and how to distribute it, create a plan for publication and monitor its implementation.

5. Press and information organizations choose the source of information based on the nature of the work of the organization.

6. Mention the author of the message or text from the information resource in the comments.

7. Continuous analysis of the methods and means of using information resources by the press and information organizations serves as a modern tool in the use of information resources to predict the situation that will occur after the start of its publication or distribution by the media.

Sources of information resources of the press and information organizations should know how they assess each situation in the world of information and present them to the public, at what time and for what purpose. Both of them should come before all other stages of planning. It should be noted that the most common shortcoming in the planning of the use of information resources by the press and information organizations is the inability to clearly define the purpose of the disseminated information or articles in the press.

An accurate and reasonable expression of the purpose of the press and information of the organization allows a clear answer to the question of why it is acting. When choosing methods and means of using information resources of the press and information organizations, it is necessary to ensure that the organization's materials or publications in the media are relevant for its activities. The expression of purpose in the use of information resources by the press and information organizations should have a clear, unambiguous and quantitative value. One of the important elements of planning the use and application of information resources by the press and information organizations is to identify and study the scope of targeted communication of the usefulness of information. If the information provided is aimed at the entire population, it is advisable to direct specific information resources to specific groups of people. In this case, the method of selective use of information resources in the press and information organizations will be more effective.

An information resource is a collection of information, news and articles published in the press. It discusses in detail issues related to various credible reports, data and media at different times. Another task of the press and information organizations is 


\section{Modern Methods and Means of Providing the Press and Information Organizations with Information Resources}

to familiarize themselves with the methods and methods of storing and distributing information resources. It is also important to divide information resources into separate components. This is one of the responsibilities of the press and media organization. Although information resources are assigned for a specific period, they should be constantly reviewed and clarified as public opinion changes. The optimal amount of information resources is determined by the experience of management and the attitude of the public to the organization. Understanding the importance of information resources in the press and information organizations has a significant impact on the success of a media organization or press publication. The selection of data from an information resource and the choice of means of its distribution are interrelated. In this case, the main responsibility for the choice of media falls on the press and information organizations.

In the media and print media, information and information is obtained through partner media, formed as an information resource, and distributed selectively. This requires journalists and editorial experience with the ability to sort information that has a deep understanding of the needs of the time in selecting the type of media and a particular media outlet. The main task of disseminating information through the press and information organizations is to deliver the message that is important to the public to the largest number of potential users. The tasks of disseminating information in the press and information organizations, publishing articles in the press, the effective use of modern means of using information resources and the use of specific methods should always be in the forefront.

In short, every professional press and media employee is required to have a high level of knowledge and skills in understanding modern methods and means of providing information resources to the press and information organizations. Reform of the republican press and information organizations It is important to use modern methods of public involvement based on the tasks of the organization in which we operate through the principle of press-information, information-resource. Another issue related to the development of the press is the reform of the system of delivery of newspapers to readers. Because the printed publications do not reach the consumer on time. As a result, the relevance of published articles loses their value in terms of time. So, first of all, it is urgent to create a system that ensures the timely delivery of each publication to the reader.

We would like to dwell on another issue that needs to be resolved. It is the reliability of the information disseminated by the press and information organizations. Legal publications and the media are unlikely to give anyone progress in this regard. Because they have their own information resource base. Centuries later, the current state of society is judged by it. Therefore, printed publications can achieve the desired result if they gather the necessary information resources from websites or blogg ing and use them for their intended purpose. The message given in the press and information organizations and every word has its own responsibility. Once it is published in the press, it can be neither edited nor deleted when it is published in an online publication.

In fact, the press and information organizations are the mirror of our lives. That is, it is a source that transmits the process of events from generation to generation. While reading the press directs a person to a book, online publications and the media open the door to deep thinking, a broad outlook through reading and listening. In general, the constant search for reliable news and information from the media for the sustainable development of both the press and information organizations is a global topic of today. It is also undeniable that in some media and information organizations, too much simplified or inaccurate information is disseminated to users and published on the Internet as it is, without providing and editing the message and information to the specialists of the information resource database. The border between brevity, simplicity and simplicity has disappeared. Quickly prepared news, reports do not invite the reader to comment. If it is necessary to make a sensational report just to get a "like", then it is not necessary to talk about the role of the media in the development of thinking, worldview.

\section{CONCLUSION}

Unfortunately, in today's era, the news of a bad event or crime, which is quickly forgotten, attracts more and more people. It is working for "hype" that leads to the spread of such bad news. If the press and information organizations do not set an example, it is clear that this trend will continue to grow. It is not a question of concealing information, but of ensuring the diversity of information and objective coverage of reality. That is, information is not a well-developed, perfect subject, it is a constant movement, a specific process. With a little work, the reader not only reads the dry information, but also sees its causes and consequences, the general course of events.

In his congratulatory message to the team, President Shavkat Mirziyoyev noted that the analysis of positive changes in our life in the media, the strengthening of a healthy critical spirit drew attention to a very important aspect, both ethically and professionally. According to the head of our state, various discussions and disputes in the field of information should be based primarily on the principles of justice and impartiality, be within the framework of law and ethics, and not turn into personal prejudices and hatred, a way to gain false prestige. there should be absolutely no place in our media space. In conclusion, we believe that the press and information organizations are able to fulfill the tasks set by the requirements of the time, fully complying 


\section{Modern Methods and Means of Providing the Press and Information Organizations with Information Resources}

with the proposals and recommendations set out in the article, while processing and distributing the information resources they have collected among the general public.

\section{REFERENCES}

1) Mirziyoev Sh.M. Critical analysis, strict discipline and personal responsibility should be the daily rule of every leader. Speech of the President of the Republic of Uzbekistan at the meeting of the Cabinet of Ministers of the Republic of Uzbekistan on the results of 2016 and prospects for 2017. // People's word newspaper. January 16, 2017. №11.

2) Congratulations of the President of the Republic of Uzbekistan on June 27, 2020: To the staff of the press and mass media. People's Word newspaper June 27. 2020.

3) Resolution of the President of the Republic of Uzbekistan dated May 24, 2018 No PP-3737 "On the establishment of the Uzbek University of Journalism and Mass Communications." URL: http://lex.uz 24.05.2018.

4) Gazeta.ru, "The Governor of New Jersey spotted vacationing on a closed public beach." -

URL: https://www.gazeta.ru/socia I / news / 2017/07/03 / n 10256990.shtml.

5) Scientific-methodical electronic journal, “Foreign languages in Uzbekistan” journal.fledu.uz. № 6/2019.

6) Qahhor A. Fair speech is in the heart of the reader. Source: "Youth" magazine, issue 10, 2015.

7) About mass media (new edition), Law of the Republic of Uzbekistan, Adopted on January 15, 2007 // People's word, 2007, January 16.

8) Universal Declaration of Human Rights, // www: un.org.

9) On the transparency of public administration, Law of the Republic of Uzbekistan, Adopted on May 5, 2014.// People's speech. May 5, 2014.

10) Alimov B. Journalism education: a new international collaboration

11) phase. Electronic journal “Foreign languages in Uzbekistan”, № 5 (13) / 2016. https://journal.fledu.uz/uz/zhurnalistika-talimi-hal-aro-hamkorlikning-yangi-bos-ichi.

12) Ataeva N; Salaeva M; Hasanov S. General pedagogy (Fundamentals of pedagogical theory and practice). Study guide. Book II. X. Based on the general edition of Boboevnnnr. Tashkent: "Science and technology", 2013, 860 pages.- p. 6- 8.

13) Journalism education. - URL: // https: uchenbnikfree / com /.

14) Ivanova V.A; Levina T.V. Pedagogy. FGOU VPO Krasnoyarsk

15) State Agrarian University, Distance Learning Center. //http://www.kgau.ru/distance/mf_01/ped-asp/01_01.html.

16) Fateeva I. A. Journalism education in Russia: theory, history, modern practice: dis. Dr. philol. sciences. Yekaterinburg, 2008. -p. 28. 